\title{
ISOLASI DAN IDENTIFIKASI ESCHERICHIA COLI PADA AIR WUDHU DI MASJID YANG BERADA DI KOTA TANGERANG
}

\author{
*Jamilatun M, ${ }^{*}$ Aminah
}

\begin{abstract}
Abstrak
Air sebagai salah satu kebutuhan utama dalam menunjang kehidupan manusia beresiko membawa penyakit bawaan air (water borne disease) jika tidak memenuhi syarat kesehatan. Salah satu pemanfaatan air adalah digunakan sebagai air wudhu. Penelitian ini bertujuan untuk mengetahui keberadaan Escherichia coli pada air wudhu di Masjid yang berada di Kota Tangerang. Desain penelitian yang digunakan adalah penelitian deskriptif dengan uji laboratorium dengan jumlah sampel 15. Pengambilan sampel dilakukan pada masjid yang telah ditentukan, selanjutnya dilakukan pemeriksaan laboratorium yang meliputi nilai MPN coliform untuk mengetahui kualitas air, dilanjutkan isolasi dan identifikasi Escherichia coli pada media EMBA (Eosin Methylin Blue Agar) serta uji produksi hemolisin pada media agar darah. Hasil penelitian menunjukkan bahwa Terdapat keberadaan bakteri Escherichia coli pada air wudhu di Masjid yang berada di Kota Tangerang. Dari hasil identifikasi Escherichia coli, dapat diketahui dari 15 sampel yang diteliti terdapat 6 sampel air wudhu yang teridentifikasi E.coli, dua diantaranya bersifat hemolisis. Oleh karena itu penjaga masjid untuk senantiasa menjaga kebersihan air bak penampungan dengan teratur serta kebersihan lingkungan di sekitar masjid.
\end{abstract}

Keywords: Isolasi, Identifikasi, Escherichia coli, air wudhu. *Poltekkes Kemenkes Banten 


\section{PENDAHULUAN}

Air bersih adalah air yang digunakan untuk keperluan seharihari yang kualitasnya memenuhi syarat kesehatan dan dapat diminum apabila telah dimasak (Permenkes No.416 Tahun 1990). Dampak yang ditimbulkan dari kualitas air yang tidak memenuhi baku mutu air bersih adalah terjadinya berbagai penyakit dengan cara mengkonsumsi air secara langsung maupun pendayagunaan air yang tidak memenuhi standar air bersih (Soemirat, 2003). Data dari WHO (1998) menyebutkan bahwa separuh dari populasi dunia mengalami penyakit yang berhubungan dengan kekurangan air dan air terkontaminasi yang berisiko pada timbulnya penyakit bawaan air seperti diare yang banyak mengakibatkan kematian.

Masjid merupakan tempat ibadah umat Islam, salah satunya untuk sholat. Sebelum melakukan sholat selalu didahului dengan berwudhu yang dalam rangkaiannya terdiri dari berkumur, membasuh muka, tangan, dan kaki. Saat berkumur, air wudhu dimasukkan ke dalam mulut, sehingga terdapat sebagian air yang tersisa di dalam mulut. Jika air wudhu dari penampungan tidak memenuhi syarat, diantaranya secara mikrobiologis maka dapat menimbulkan penyakit karena terdapat mikroorganisme di dalamnya. Mikroorganisme dalam air dapat diketahui keberadaannya melalui bakteri-bakteri yang menjadi indikator keberadaannya. Indikator yang umum diketahui adalah Escherichia coli. E. coli merupakan bakteri yang berbentuk batang, gram negatif, yang merupakan penghuni normal dalam saluran pencernaan manusia dan hewan. Namun demikian E. coli merupakan salah satu bakteri penyebab diare. Penelitian yang telah dilakukan oleh Alikhani, et.al. (2013), menyebutkan bahwa E.coli merupakan agen penyebab diare. E.coli merupakan bakteri penyebab diare dengan prosentase tertinggi (Osman et al., 2012). Terdapat beberapa serotipe dari E.coli yang menyebabkan diare (Bonyadian et.al. (2010); Sahar et.al. 
(2013)). Berdasarkan latar belakang tersebut, maka dalam penelitian ini dilakukan pemeriksaan Escherichia coli sebagai indikator kualitas mikrobiologis pada air wudhu di Masjid yang berada di Kota Tangerang.

\section{METODOLOGI PENELITIAN}

\section{Lokasi dan Waktu Penelitian}

Penelitian ini dilaksanakan pada bulan September - Oktober 2015. Desain digunakan adalah penelitian deskriptif dengan uji laboratorium. Populasi dalam penelitian ini adalah seluruh air dari Masjid yang berada di Kota Tangerang. Sampel diambil secara purposive sampling.

\section{Pengambilan Sampel}

Pengambilan sampel dilakukan dengan cara air dimasukkan ke dalam botol steril sebanyak $100 \mathrm{ml}$ secara aseptis. Kemudian sampel ditempatkan dalam wadah botol dan dibawa ke Laboratorium Mikrobiologi Jurusan Analis Kesehatan Poltekkes Kemenkes Banten.

\section{Isolasi dan Identifikasi Escherichia} coli

Sebelum dilakukan isolasi dan identifikasi E.coli, dilakukan uji MPN. Pemeriksaan MPN menggunakan ragam 3-3-3 terdiri dari 3 uji yaitu uji penduga yang menggunakan media LB (Lactosa Broth), uji penegasan menggunakan media BGLB (Brilliant Green Lactose Bile Broth), dan uji pelengkap dengan menggunakan EMBA (Eosin Methylin Blue Agar) untuk identifikasi Escherichia coli.

\section{Uji Produksi Hemolisin}

Produksi hemolisin ditentukan berdasarkan adanya zona hemolisis yang dibentuk oleh isolat E. coli. Isolat ditanam pada blood agar base dengan penambahan darah domba $5 \%$, kemudian diinkubasi pada suhu $37^{0} \mathrm{C}$ selama $18-24$ jam. Terlihatnya zona bening di sekitar koloni setelah 18 jam inkubasi pada suhu $37^{0} \mathrm{C}$ dianggap sebagai hasil positif produksi hemolisin (Suardana, 2014 dan Hendrayana et.al., 2012). 


\section{Analisis Data}

Data hasil penelitian disajikan secara deskriptif dalam bentuk tabel ataupun gambar (Steel dan Torrie, 1995). Data hasil pengamatan coliform dianalisa menggunakan metode Most Probable Number (MPN) ragam 3-3-3. Data hasil identifikasi Escherichia coli disajikan dalam bentuk gambar.

\section{HASIL}

Tabel 1.

Hasil Pengamatan Tabung Positif pada Air Wudhu dari Uji Penduga (Presumtive test) pada Media LBDS (Lactose Broth Double Strength) dan LBSS (Lactose Broth Single Strength)

\begin{tabular}{|c|c|c|c|c|c|c|c|c|c|c|c|}
\hline \multirow{3}{*}{$\begin{array}{l}\text { No } \\
1 \\
1\end{array}$} & \multirow{3}{*}{$\begin{array}{r}\text { Sampel } \\
\text { Sampel 1 }\end{array}$} & \multirow{2}{*}{\multicolumn{3}{|c|}{$\begin{array}{c}\text { LBDS } \\
(\mathbf{1 0 m l}) \\
3\end{array}$}} & \multirow{2}{*}{\multicolumn{3}{|c|}{$\begin{array}{c}\text { LBSS } \\
(\mathbf{1 m l}) \\
3\end{array}$}} & \multirow{2}{*}{\multicolumn{3}{|c|}{$\begin{array}{c}\text { LBSS } \\
(0.1 \mathrm{ml})\end{array}$}} & \multirow{3}{*}{$\begin{array}{c}\begin{array}{c}\text { Kombinasi Tabung } \\
\text { Positif }\end{array} \\
3-3-3\end{array}$} \\
\hline & & & & & & & & & & & \\
\hline & & + & + & + & + & + & + & + & + & + & \\
\hline 2 & Sampel 2 & + & + & + & + & + & + & + & + & + & $3-3-3$ \\
\hline 3 & Sampel 3 & + & + & + & + & + & + & + & + & + & $3-3-3$ \\
\hline 4 & Sampel 4 & + & + & + & + & + & + & - & - & + & $3-3-1$ \\
\hline 5 & Sampel 5 & + & + & + & + & + & + & - & + & - & $3-3-1$ \\
\hline 6 & Sampel 6 & + & + & + & + & + & + & + & + & + & $3-3-3$ \\
\hline 7 & Sampel 7 & - & - & + & - & - & + & - & - & - & $1-1-0$ \\
\hline 8 & Sampel 8 & + & + & + & + & + & + & - & - & - & $3-3-0$ \\
\hline 9 & Sampel 9 & + & + & + & + & + & + & - & - & - & $3-3-0$ \\
\hline 10 & Sampel 10 & + & + & + & + & + & + & + & + & + & $3-3-3$ \\
\hline 11 & Sampel 11 & + & + & + & + & + & + & - & - & - & $3-3-0$ \\
\hline 12 & Sampel 12 & + & + & + & + & + & + & - & - & - & $3-3-0$ \\
\hline 13 & Sampel 13 & - & - & - & - & - & - & - & - & - & $0-0-0$ \\
\hline 14 & Sampel 14 & + & + & + & + & + & + & + & + & + & $3-3-3$ \\
\hline 15 & Sampel 15 & + & + & + & + & + & + & + & + & + & $3-3-3$ \\
\hline
\end{tabular}


Tabel 2.

Hasil Uji MPN Coliform pada Air Wudhu dari Uji Penegasan (Confirmative

Test) pada Media BGLB (Brilliant Green Lactose Bile Broth) dan

Kesesuaian dengan persyaratan PERMENKES

416/MEN.KES/PER/IX/1990 (Kadar Maksimum MPN Coliform yang diperbolehkan 50 per $100 \mathrm{ml}$ )

\begin{tabular}{llccc}
\hline No & Sampel & $\begin{array}{c}\text { Kombinasi } \\
\text { Tabung } \\
\text { positif }\end{array}$ & $\begin{array}{c}\text { MPN } \\
\text { Coliform } \\
\text { per 100 ml }\end{array}$ & Keterangan \\
\hline 1 & Sampel 1 & $3-2-2$ & 210 & Tidak memenuhi syarat \\
2 & Sampel 2 & $2-0-0$ & 9 & Memenuhi syarat \\
3 & Sampel 3 & $3-3-0$ & 240 & Tidak memenuhi syarat \\
4 & Sampel 4 & $3-0-0$ & 23 & Memenuhi syarat \\
5 & Sampel 5 & $3-0-0$ & 23 & Memenuhi syarat \\
6 & Sampel 6 & $2-2-2$ & 28 & Memenuhi syarat \\
7 & Sampel 7 & $1-1-0$ & 7 & Memenuhi syarat \\
8 & Sampel 8 & $3-3-0$ & 240 & Tidak memenuhi syarat \\
9 & Sampel 9 & $1-0-0$ & 4 & Memenuhi syarat \\
10 & Sampel 10 & $3-1-0$ & 48 & Memenuhi syarat \\
11 & Sampel 11 & $3-3-0$ & 240 & Tidak memenuhi syarat \\
12 & Sampel 12 & $2-2-0$ & 21 & Memenuhi syarat \\
13 & Sampel 13 & $0-0-0$ & 0 & Memenuhi syarat \\
14 & Sampel 14 & $3-3-3$ & 1100 & Tidak memenuhi syarat \\
15 & Sampel 15 & $3-1-0$ & 48 & Memenuhi syarat \\
\hline
\end{tabular}

Tabel 3.

Hasil Pengamatan Koloni Escherichia coli pada Media EMBA (Eosin Methylen Blue Agar) dan Uji Hemolisis pada Agar Darah

\begin{tabular}{llcc}
\hline No & Sampel & E.coli $(+/-)$ & Hemolisis $(+/-)$ \\
\hline 1 & Sampel 1 & - & - \\
2 & Sampel 2 & + & + \\
3 & Sampel 3 & - & - \\
4 & Sampel 4 & - & - \\
5 & Sampel 5 & + & + \\
6 & Sampel 6 & + & - \\
7 & Sampel 7 & - & - \\
8 & Sampel 8 & - & - \\
9 & Sampel 9 & - & - \\
10 & Sampel 10 & - & - \\
11 & Sampel 11 & - & - \\
12 & Sampel 12 & + & - \\
13 & Sampel 13 & - & - \\
14 & Sampel 14 & + & - \\
15 & Sampel 15 & + & - \\
\hline
\end{tabular}



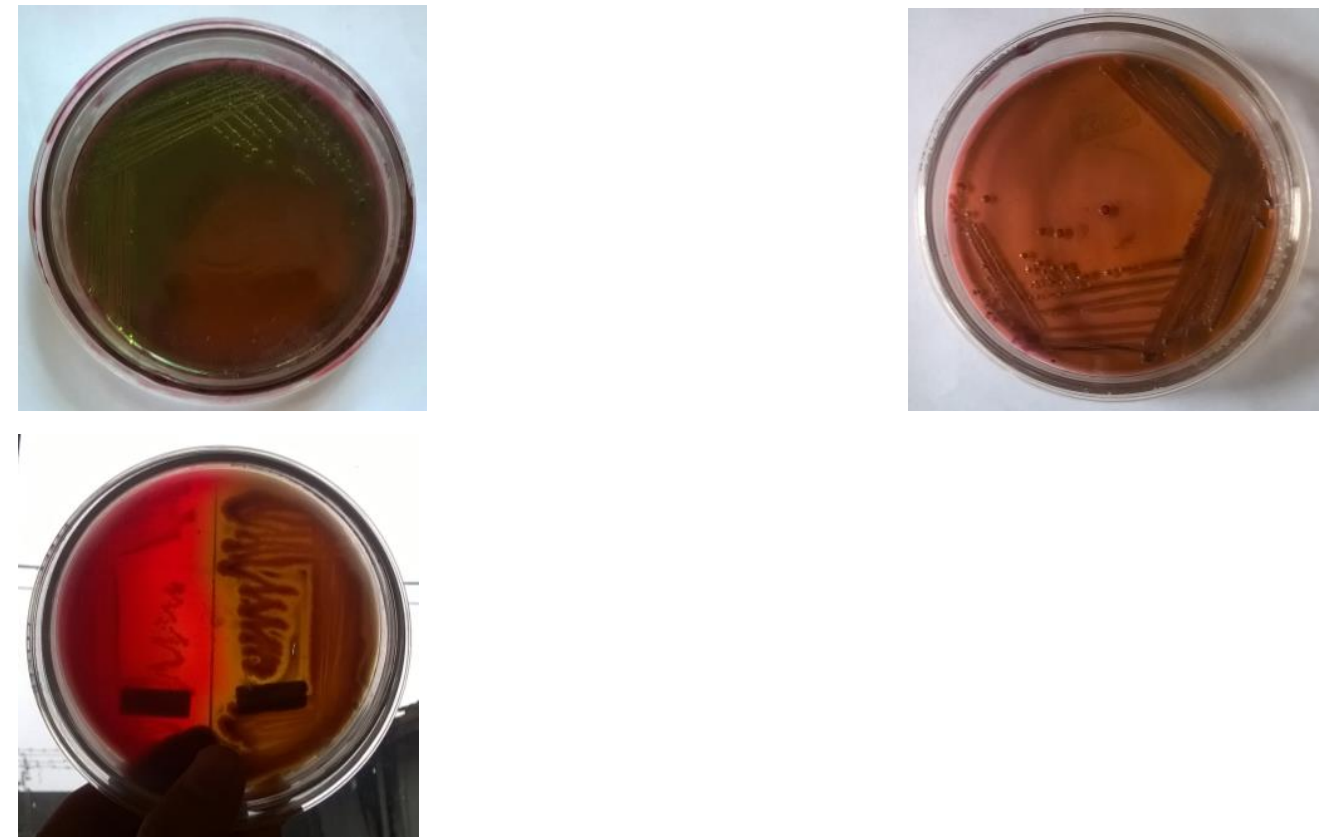

a

$\mathrm{b}$

C

Gambar 1. (a) Media EMBA yang ditumbuhi bakteri E.coli, (b) Media EMBA yang tidak ditumbuhi bakteri E.coli, (c) Media Agar Darah yang hemolisis.

\section{PEMBAHASAN}

Hasil pemeriksaan MPN coliform dapat dilihat pada Tabel 2. Pada tabel tersebut, dapat diketahui dari 15 sampel yang diteliti terdapat 5 sampel air wudhu yang tidak memenuhi kualitas standar yang telah ditetapkan

\section{PERMENKES}

416/MEN.KES/PER/IX/1990 (kadar maksimum MPN coliform yang diperbolehkan 50 per $100 \mathrm{ml}$ ), yaitu pada sampel 1, sampel 3, sampel 8, sampel 11, dan sampel 14. Nilai MPN yang melebihi standar ini menunjukkan bahwa air wudhu telah tercemar oleh bakteri coliform. Menurut penelitian yang telah dilakukan oleh Hope et al. (2014), salah satu sumber hadirnya bakteri coliform adalah dari bak penampungan air, sampah di lingkungan sekitar, udara terbuka, air tanah yang terkontaminasi air cucian dan air hujan, serta limbah rumah tangga dan limbah domestik. Dan ditambahkan oleh Mashiatullah et al. (2010), bakteri coliform bisa masuk ke 
dalam tampungan air melalui kotoran hewan, burung, sisa sampah dan sisa pertanian yang terbawa oleh angin. Selain itu, juga kondisi septitank saat musim hujan yang mengakibatkan kotoran manusia tercampur ke dalam aliran air dekat tampungan.

Adanya bakteri coliform dalam badan air menunjukkan kemungkinan adanya bakteri patogen yang berbahaya bagi kesehatan. Sehingga penggunaan air wudhu yang tercemar ini bisa menyebabkan penyakit dikarenakan bakteri coliform bisa masuk melalui mulut, hidung, telinga dan kulit. Sebagaimana dinyatakan oleh Nwachukwu and Ume (2013) dan Aziz et al., (2013), air yang tercemar dapat beresiko bagi kesehatan karena bisa menjadi perantara penularan penyakit seperti disentri, kolera, diare, tipes, shigellosis, salmonellosis.

Menurut Ramadan (2015) bakteri coliform merupakan golongan mikroorganisme yang lazim digunakan sebagai indikator, karena densitasnya berbanding lurus dengan tingkat pencemaran air. Bakteri ini dapat mendeteksi patogen pada air. Selain itu, bakteri ini juga memiliki daya tahan yang lebih tinggi daripada patogen serta lebih mudah diisolasi dan ditumbuhkan (Doyle, 2006). Sehingga bakteri ini dapat menjadi sinyal untuk menentukan suatu sumber air telah terkontaminasi oleh patogen atau tidak (Pracoyo, 2006). Bakteri coliform dapat memfermentasi laktosa untuk menghasilkan asam dan gas pada suhu $35^{\circ} \mathrm{C}-37^{\circ} \mathrm{C}$. Contoh bakteri coliform antara lain Escherichia coli.

Hasil identifikasi Escherichia coli pada penelitian ini dilihat pada Tabel 3. Pada tabel tersebut, dapat diketahui dari 15 sampel yang diteliti terdapat 6 sampel air wudhu yang teridentifikasi koloni E.coli, yaitu pada sampel 2, sampel 5, sampel 6, sampel 12, sampel 14 dan sampel 15. Dan dua diantaranya bersifat hemolisis yaitu pada sampel 2 dan sampel 5. Berdasarkan penelitian yang telah dilakukan oleh Huwaida (2014), faktor yang mempengaruhi adanya bakteri E.coli adalah kedalaman sumber air, jarak antara jamban dengan sumber air bersih, jarak antara septitank dengan sumber air.

Bakteri Escherichia coli merupakan organisme penghuni utama di usus besar, hidupnya komensal dalam kolon manusia dan merupakan mikroorganisme normal yang terdapat dalam kotoran manusia, baik sehat maupun sakit. Oleh karena itu, dikenal juga dengan istilah koli tinja. Dalam satu gram kotoran manusia terdapat sekitar seratus juta bakteri Escherichia coli. (Jawert, dkk, 2005). Sehingga 
Escherichia coli dapat digunakan sebagai indikator adanya kontaminasi feses atau indikasi adanya pencemaran tinja manusia yang dapat menyebabkan masalah kesehatan seperti diare, serta indikator adanya mikroorganisme enterik patogen lainnya yang bisa menjadi agen penularan penyakit (Tortora et al., (2004) dan Hope et al., (2014).

Hasil Identifikasi E.coli pada media $E M B A$ dapat dilihat pada gambar 3 . Hasil pertumbuhan E.coli pada EMBA memperlihatkan koloni berwarna hijau metalik, diameter 2 - $3 \mathrm{~mm}$ dengan titik hitam di bagian tengah koloni (Suardana dkk., 2014). EMBA adalah media selektif dan media diferensial. Media ini mengandung eosin dan metilen biru, yang menghambat pertumbuhan bakteri Gram positif, maka media ini dipilih untuk bakteri Gram negatif. EMBA juga mengandung karbohidrat laktosa, dengan adanya karbohidrat laktosa bakteri Gram negatif terdiferensiasi berdasarkan pada kemampuan mereka untuk memfermentasi laktosa. Warna media sebelum pemupukan bakteri berwarna merah keunguan. Perubahan warna hijau metalik pada media $E M B A$ karena Escherichia coli dapat memfermentasi laktosa yang mengakibatkan peningkatan kadar asam dalam media.
Kadar asam yang tinggi dapat mengendapkan methylen blue dalam media EMBA.

Dari hasil penelitian ini dapat diketahui, beberapa sampel menunjukkan coliform yang tinggi, namun tidak semua jumlah coliform yang tinggi menunjukkan adanya bakteri E.coli. Menurut Archer (1984) dalam Mashiatullah et al. (2010), jika yang diketahui hanya jumlah coliformnya saja yang tinggi, maka kemungkinan besar disebabkan oleh lingkungan, yang menjadi indikasi adanya pencemaran, yang secara tidak langsung dapat menjadi agen bagi patogen lainnya.

\section{Simpulan}

Terdapat keberadaan bakteri Escherichia coli pada air wudhu di Masjid yang berada di Kota Tangerang. Dari hasil identifikasi Escherichia coli, dapat diketahui dari 15 sampel yang diteliti terdapat 6 sampel air wudhu yang teridentifikasi koloni E.coli. Dan dua diantaranya bersifat hemolisis. Hasil pertumbuhan E. coli pada EMBA memperlihatkan koloni berwarna hijau metalik. 


\section{Saran}

Disarankan kepada para penjaga masjid untuk senantiasa menjaga kebersihan air bak penampungan dengan teratur serta kebersihan lingkungan di sekitar masjid.

\section{DAFTAR PUSTAKA}

Alikhani, et.al. 2013.Prevalence and antibiotic resistance patterns of diarrheagenic Escherichia coli isolated from adolescents and adults in Hamedan, Western Iran. Iranian Journal of Microbiology.Volume 5 Number 1: 42-47.

Aziz Ahmed, Tarique Mahmood Noonari, Habibullah Magsi, Amanullah Mahar. 2013. Risk Assessment of Total and Faecal Coliform Bacteria From Drinking Water Supply of Badin City, Pakistan. Journal of Environmental Professionals Sri Lanka, 2013:Vol. 2 -No. 1, 52-64

Bonyadian, et.al. 2010. Identification \& characterization of Shiga toxinproducing Escherichia coli isolates from patients with diarrhoea in Iran. Indian J Med Res 132, September 2010, pp 328-331

Doyle, M.P., Erickson, M.C. 2006. Closing The Door On The Fecal Coliform Assay. Microbe 1, hal. 162-163.

Hendrayana, M.A., et.al., 2012. Deteksi Bakteri Escherichia Coli Serotipe O157 Pada Daging Babi Dari Pedagang Daging Babi Di Kota Denpasar. MEDICINA, 43:3-8.

Hope C. Okereke1, Eze S. Ogbonnaya2, Sunday O. Eze. 2014. Bacteriological and Physicochemical Qualities of Some
Borehole Waters in Aba South Metropolis, Abia State Nigeria. Asian Journal of Natural \& Applied Sciences Vol. 3(3) September 2014

Huwaida, RN. 2014. Faktor-Faktor yang Mempengaruhi Jumlah Escherichia coli Air Bersih pada Penderita Diare di Kelurahan Pakujaya Kecamatan Serpong Utara Kota Tangerang Selatan Tahun 2014. Skripsi. FKIK UIN Syarif hidayatullah. Jakarta.

Jawert, Melnick, Adelberg, 2005, Mikrobiologi Kedokteran (Medical Microbiology), Salemba Medika, Jakarta

Mashiatullah, R. M. Qureshi, T. Javed, M. S. Khan, M. Z. Chaudhary And F. Khalid. 2010. Bacteriological (Fecal And Total Coliform) Quality Of Pakistani Coastal Water. The Nucleus 47, No. 2 (2010) 173-180. Issn 0029-5698.

Menteri Kesehatan R.I., 1990. Peraturan Menteri Kesehatan R.I, No. 416/Menkes/Per/IX/1990 tentang syarat-syarat dan pengawasan kualitas air, Jakarta.

Menteri kesehatan RI. 2002. Keputusan Menteri Kesehatan Republik Indonesia Nomor 1405/menkes/sk/xi/2002 tentang Persyaratan Kesehatan Lingkungan Kerja Perkantoran dan industry. Departemen kesehatan RI.

Michael JP Jr., E.C.S. Chan. 2012. Dasar-dasar mikrobiologi. Jakarta: Universitas Indonesia

Nwachukwu, E., \& Ume, C. A. (2013). Bacteriological and physicochemical qualities of drinking water sources in local area of Eastern Nigeria. J. Environ. Sci. Water Res., 2(9), 336 - 341. 
Osman, et al. 2012. Bacterial etiology of diarrhoeal diseases in children under 5 years old in Ombadda Hospital - Sudan. Sudanese Journal Of Public Health - July 2012, VOL. 7 No 3

Pracoyo, N.E. 2006. Penelitian Bakteriologik Air Minum Isi Ulang di Daerah Jabotabek. Cermin Dunia Kedokteran 152, hal. 37-40.

Ramadan, M. Usama Mohammed Abdul-Raouf and Elsayed Khalaf Bakhiet. 2015. Microbial Evaluation of Some Groundwater Resources for Human Domestic Consumption in the Western Area of the River Nile Basin of Assuit Governorate, Egypt. J. Eco. Heal. Env. Vol. 3, No. 1, 1525 (2015).

Sahar et.al. 2013. Prevalence and characterization of Shiga toxin O157 and non-O157 enterohemorrhagic Escherichia coli isolated from different sources in Ismailia, Egypt. Academic Journals. Vol. 7(21), pp. 2637-2645
Soemirat, J. 2003. Toksikologi lingkungan. Yogyakarta. Gadja Mada University

Steel, R.G.D., and J.H. Torrie. 1995. Prinsip dan Prosedur Statistika. PT. Gramedia Pustaka, Jakarta.

Suardana, I.W. et al., 2014. Identifikasi Escherichia Coli O157:H7 Dari Feses Ayam Dan Uji Profil Hemolisisnya Pada Media Agar Darah. Jurnal Kedokteran Hewan. Vol. 8 No. 1

Tortora, GJ B.R. Funke, C.L. Case. Microbiology: An Introduction, 8th Ed. The Benjamin Cummings Publishing Co. Inc, USA, 2004, p.717.

WHO. 1998, 'Treatment Critical to Curbing Waterborne Disease', Questia: Journal of Environmental Health, vol. 60. 